\title{
Environmental education for public awareness: The role of educational administrators and planners
}

\author{
Anijah-Obi Franca ${ }^{1}$, Eneji Chris-Valentine Ogar $^{2 \star}$ and Ubom Bassey A.E. ${ }^{3}$ \\ ${ }^{1}$ Environmental Education Unit, Department of Curriculum and Teaching, University of Calabar, Nigeria. \\ ${ }^{2}$ Department of Educational Administration and Planning, University of Calabar, Nigeria. \\ ${ }^{3}$ Department of Science and Environmental Education, University of Abuja, Nigeria.
}

Accepted 18 December, 2012

\begin{abstract}
The paper argues that the unique position of the educational system as the initiator and executor of educational policies has made it compelling for educational administrators and planners to champion the effective implementation of environmental education as a strategy for improving public awareness, environmental quality and hopefully propel sustainable development in Nigeria. The objectives of this paper therefore are four fold: to present where we are in terms of policy issues, what the challenges and opportunities are, what we should be doing and the role of educational planners. The paper concludes that environmental education and the education process should assume a position of prominence and importance if the goal of sustainable development is to be achieved and stressed the need to urgently embrace the "green curriculum" and mainstream environment in education at all levels.
\end{abstract}

Key words: Public awareness, environmental education, role, educational administrators, planners.

\section{INTRODUCTION}

The environmental problems of contemporary Africa and the world at large are so pervasive and worrisome because of their obvious consequences for mankind and sustainable development. Today there is a national and international understanding of the need to minimize possible negative human activities that cause environmental changes and maximize major advantages derivable through environmental conditions that could result from a planned and sustainable use of the natural environments. This is evidenced in the Millennium Summit Declaration in which explicit reference was made to critical environmental issues such as biodiversity-loss, deforestation, desertification, climate change and water management. Goal 7 of the millennium development Goals (MDGs) seeks to ensure environmental sustainability which is indicative of the global concerns for the environment. One of the major issues of the G8 summit in Germany in 2007 is climate change. Many Nigerians

\footnotetext{
${ }^{*}$ Corresponding author. E-mail: vcogareneji@yahoo.com.
}

participated in the Copenhagen Summit on Environment in 2009. These global interests about the predicament of the environment, especially in the face of prevailing mass poverty, disease, filth, malnutrition, hunger, population growth, unemployment and pollution of air, land and water, has made it compelling for most countries of the world to embrace Environmental Education (EE) as a precondition for environmental quality. This is based on the belief that environmental education will most likely improve public awareness, engender eco-friendly attitudes and develop management skills and strategies that will minimize environmental damage. Indeed most efforts made by the Nigerian government and nongovernmental organizations (NGOs) have failed woefully. This is largely so because, the crusade for environmental quality is being focused more on the environmental front, such as: environmental sanitation exercises, clean-up campaigns, seminars, workshops and other mundane activities which merely attack the symptoms rather than the problems themselves. Other measures to control erosion, desertification etc. have not yielded significant success. The general feeling today is the need to focus 
more on the human front -changing attitudes, values, perceptions, habits and inclinations through education which is more likely to inculcate in the citizens a sustained culture of environmental ethic and discipline capable of engendering environmental friendliness.

It is believed that successful control of environmental problems will depend to a great extent on the way people perceive their environment and their concomitant behavior, because it is the human mind that masterminds human behavior. And since environmental problems are basically human problems, they require a radical change of attitude and complete transformation in the way people behave and the way they use the earth's resources. To bring about this attitude change people need to have a modified perception of and positive behavior towards the environment. Indeed, educational administrators and planners can no longer afford to remain aloof or shy away from their responsibilities, in the face of global environmental problems, that are threatening the biosphere (the domain of life on earth), thereby putting the lives of millions of people who inhabit it in jeopardy. It becomes imperative to focus more on the human rather than on the physical front, for the solution of environ-mental problems considering that education as a vital instrument of systematic change is fundamental if we are to successfully change people's attitudes towards the environment (Meyers, 2004).

\section{POLICY ISSUES}

The National Conservation Education Strategy (NCES) directed the infusion of Environmental Education (EE) elements into school curricula at all levels, starting with the citizenship education curriculum and the introduction of Environmental Education in Nigerian universities. Agenda 21 also presents the programmes of action for achieving sustainable development in the $21^{\text {st }}$ century. The major areas of emphasis for Environmental Education as adopted in the global environmental action plan for the $21^{\text {st }}$ century are;

(1) To reorient education towards sustainable development

(2) To increase public awareness

(3) To promote training (Grubb et al., 1995).

The National Policy on Environment (1989) recommendded that government shall:

(i) Promote comprehensive curriculum reviews that integrate environment and development concepts in the educational systems;

(ii) Support the development of courses and programmes leading to the award of degrees and diplomas in environmental education, environmental sciences, and management and technology;

(iii) encourage practical training programmes for graduates of tertiary institutions to prepare them for labor market requirements and creation of sustainable livelihoods;

(iv) strengthen vocational training that facilitate the development and assimilation of environmentally sound, socially acceptable, appropriate technology and knowhow;

(v) establish and support centres of excellence in interdisiciplinary research and education in areas of environment and sustainable development;

(vi) emphasize training and retraining of teachers, administrators and educational planners in environmental education and development issues;

(vii) assist schools to design and sustain environment related activities, including establishment of environmental awareness clubs and associations;

(viii) support public participation activities covering formal and non-formal education and training to help carry out needed changes or strengthen values, knowledge, technologies and institutions with respect to priority issues and also to support active concern for the quality of the environment among others (MDG Report, 2006).

\section{WHERE WE ARE}

It is against the above policy issues that we shall examine where we are now and the journey so far. We can safely say that presently, environmental education is gradually gaining grounds in the education curricula of the nation although it is yet to feature significantly at all levels in the school curriculum. In the tertiary institutions, educational courses which hitherto were core concerns of geography departments and the sciences are now being renamed to reflect environment issues in line with global trends and demands. For instance, we now have courses like; Environmental Biology and Environmental Science, Environmental Engineering, Environmental Protection and Management, Politics of Global Environmental Management. The course Public Health has now changed to Environmental Health. There is a new programme in the Department of Geography and Regional Planning, University of Calabar called Environmental Protection and Resources Management. Environmental education is now being taught as a distinct course under the curriculum department in few Nigerian Universities and Colleges of Education.

It is regrettable however that, efforts made at integrating environmental education into the primary and secondary school curricula have failed. Even the effort made by the National Education Research and Development Council (NERDC) in developing environmental education curricula for primary and secondary schools in Nigeria is yet to materialize into anything concrete. That 
this curriculum is yet to be operational in schools translates into denying generations of Nigerians the opportunity of being grounded in environmental education concepts at an early age (Rigg, 2006). Such would have helped the children to internalize environmental education norms and the ethics of conservation at their formative and plastic years.

In terms of public awareness, the general paucity of environmental awareness among the citizenry still leaves much to be desired. Many people do not sufficiently understand the meaning and significance of the environment. Some see it as sanitation, others see it as the wilderness, deforestation or pollution. However, there is significant interest in environmental issues, going by the number of NGO's, environmental conferences, seminars, symposia, journals, periodicals, TV and radio talk shows, researches and even government sponsored programmes on sustainability of the environment. For instance, in June 2008, there was a Cross River Stakeholders Summit on the Environment and the theme was, "Towards developing and sustaining a clean and safe environment for present and future generations". Similarly, in October, the same year, the first National Environment summit was held in Abuja with the theme: "Greening the environment for sustainable economic development". These are indications of the level of environmental awareness in the country. But how many people are really affected by all these seminars when there is no light to watch the TV and listen to the messages? These strategies are certainly not enough to achieve the desired goal of having an environmentally literate society. For instance, how many people participate in such seminars and workshops? How many people can afford to buy and read the newspapers etc? Nevertheless, one can say that some degree of awareness has been created as the entire Niger Delta agitation for resource control and environmental quality is no doubt anchored on Environmental consciousness and Environmental rights vis-à-vis the impact of oil industries on the environment. The government is also repositioning the country for sustainable development as every project receiving funding from either government or private individuals must carry out an Environmental Impact Assessment (EIA).

\section{WHAT ARE THE CHALLENGES?}

There is no doubt that some of the efforts made by the Federal government to improve the quality of the environment as mentioned earlier are quite commendable but surprisingly most of the policy initiatives have not yielded the expected results (Wiedemann and Femers,1993). One of the reasons could be that the education sector has not been given adequate emphasis in the scheme of things. Some of the problems are discussed as follows.

\section{Mainstreaming environment in education}

Nigerians should go beyond sloganeering about the environment and begin to factor in environment in whatever we do and adopt concrete actions aimed at changing human behavior such as learning for attitudinal change along the lines of environmental conservation and sustainable development. It is disturbing that Nigeria has not sufficiently embraced the "Green Curriculum", whereas all over the world attempts are being made to go green both in public and private sectors. The green concept is in line with global green consciousness of thinking globally and acting locally. The green curriculum is simply a curriculum that addresses the environmental problems beginning with our local communities. It is a curriculum that aims at inculcating in the children environmental ethics, developing their interests in nature, and promoting better and widespread understanding of the environment and sustainable development. The prevailing situation in Nigeria calls for an education programme for all citizens that focuses on the specific changes that have altered our land, air, water and vegetation as well as the consequences of these changes on all life forms including man. The general public, including those outside the formal education system, must be formally acquainted with these changes, their origins, what actions may be taken by man in order to solve contemporary environmental problems and how best man may live in harmony with his environment.

\section{Integrating EE into university GSS programme}

The major challenge of effectively integrating EE into the university GSS programme is that of relevance and uniformity in what is being imparted to students. Lecturers from different disciplines, without any course description are assigned to teach EE under the GSS programme. So, they teach anything ranging from types of soils to the different kinds of vegetation in Nigeria, etc. This is certainly not what EE is all about. Again, giving students a mere one hour exposure to EE in the present citizenship course arrangement is not enough to create the necessary awareness or change attitudes. Rather a two or three unit General Studies course in Environmental Education should be offered and run in every university undergraduate programme. Such a course should not only be compulsory but also a mandatory requirement for graduation for all students irrespective of their areas of study.

\section{Training and retraining of teachers}

Another challenge is having enough environmental educators to teach EE at all levels of the education 
system throughout the country. Teachers are critical to the achievement of environmental literacy. Greening the teacher education curriculum and retraining of all teachers with specific focus on the teaching of environmental education in schools is imperative. Train-thetrainer workshops on EE mounted in all the states of the federation for the immediate and effective take off of $E E$ curriculum in all schools will help a great deal in the production of EE teachers.

\section{Encouraging the study of EE}

Another important issue is how to encourage the youths to study EE. One way to encourage young people electing to pursue environmental education as a discipline is to award automatic scholarships and bursaries to interested candidates. There is need for a quick or immediate implementation of environmental education at the primary and secondary school levels as failure to do that will serve to negate all previous efforts and constitute huge financial loss to the NERDC.

\section{Making EE a mandatory course for admission into the university}

Another way of ensuring that majority of the citizens are exposed to EE is to make it a compulsory course in the secondary school programme. The Joint Admissions and Matriculations Board (JAMB) could make a pass in EE mandatory for entry into the university. This strategy is important because life on earth is dependent on the environment and its resources. In other words, the survival of the earth is the survival of man and the misery of the earth is the misery of man. It becomes compelling for every citizen to be environmentally aware.

\section{Funding EE programmes}

Funding is crucial to the success of any programme. The Nigerian Conservation Foundation in the early 1990's established and funded conservation clubs in Cross River State and Akwa Ibom States. Workshops were organized and teachers were trained as club leaders. As soon as the responsibility was handed over to the Ministries of Education, the clubs collapsed apparently because of lack of funding. It will be necessary to establish conservation clubs in all secondary schools in the country

\section{Supporting non-formal environmental education}

Non-formal environmental education is as important as the formal education as every citizen should be well informed about environmental issues. Effort should be made to target the farmers, traders, market women, local chiefs, opinion leaders with the aim of sensitizing them on environmental issues. This could be achieved through training and deployment of a crop of intelligent, hard working, enthusiastic and adequately motivated extension officers charged with the responsibilities of reaching the various nooks and crannies of the nation for the purpose of teaching appropriate environmental concepts; stimulating the relevant awareness and generating the appropriate attitude among the people in matters of environmental significance. These efforts must particularly focus on the rural and semi-rural communities and involve principally the enlightened members of the community whose responsibility it would be to subsequently educate their less enlightened counterparts in the community.

No doubt, every nation aspires to provide the basic needs of the citizens in terms of food, clothing, shelter, security, employment etc in order to improve their well being. But it is not possible, realistic or feasible to talk of the welfare of citizens of a nation without raising their productive potentials. This is because government cannot on its own provide every citizen with the basic necessities of life. It can only be meaningfully done through education, (i.e. equipping the individual with knowledge, appropriate skills and competencies for tasks and challenges of life). In essence, it is through education whether formal or informal that the multifarious and multidimensional human problems including poverty, ill health, unemployment, mal nutrition, over population, disease, filth, etc can be tackled (FME/UNDP, 2005).

\section{WHAT ARE THE OPPORTUNITIES?}

Nigeria is indeed blessed with considerably natural resources with highly rich and varied ecosystems from savanna forests in the extreme north to fresh water swamp forests in the south. Environmental opportunities such as biotic resources, fresh water resources, energy resources, solid minerals and vast agricultural land, if rationally and sustainably harnessed and managed will no doubt support our developmental efforts. Nigeria's liquefied gas and petrochemical projects, energy and solid minerals have the potentials of diversifying the economy which hitherto was petroleum dominated.

Therefore to say that Nigeria is blessed with considerable natural resource potentials is not in doubt. But the question is, do natural resources automatically translate to national wealth? Indeed no nation can boast of development if it cannot provide the citizens with basic needs that will raise their standard of living above the level of primary poverty. In the long run, economic development cannot be sustainable without a healthy environment. 
Sustainable renewal of our natural resources and environment would contribute significantly towards recharging and repositioning our environment to support wealth creation, employment generation, poverty reduction, growth and sustainable development. The large expanse of land, abundant sunshine and fresh water, provide potential opportunities for agricultural development in spite of the growing importance of oil and gas (FME/ UNDP, 2005). All these natural resources potentials if imparted in schools will improve public awareness and enlightenment. Furthermore, the production of environmental educators will necessarily provide employment opportunities in all sectors of the economy for the teeming Nigerians who are currently roaming the streets in search of jobs (Pretty, 1995, Rammel, et al, 2007).

\section{WHAT WE SHOULD BE DOING}

There is need to:

(i) incorporate environmental education into the curriculum at all levels of Nigerian education system, especially at the primary and secondary school levels;

(ii) develop a uniform EE course material for the GSS programme to be used by all universities;

(ii) make $\mathrm{EE}$ a mandatory course for university admission.

(iii) mount train-the-trainer workshops in EE in all states of the federation;

(iv) develop educational resources that can be used both at home and at formal school levels for creation of environmental awareness;

(v) retrain teachers to supply effective manpower for development of environmental awareness;

(vi) involve corporate bodies (Banks, oil companies etc.) to increase their social responsibility in the area of environmental awareness creation.

(vii) devote a significant part of national budget, to national creation of environmental awareness;

(viii) ensure that political decisions reflect more concern for environmental sustainability;

(ix) educate the people on sustainable consumption behavior;

(x) mobilize humanitarian groups and NGOs and retired teachers to help raise concern about poverty and famine in the community;

(xi) use community penetrating strategies to achieve desired results; and

(xii) Sponsor training of environmental education teachers with local government subventions (Torri, 2010).

\section{THE ROLE OF EDUCATIONAL PLANNERS}

The social, economic, political and environmental trends in Nigeria do have some implications for education and planning. The idea of strategic planning for environmental education is borne out of the need to draw a relationship between education, environment and sustainable development. Towards this end, the role of education planners for effective environmental literacy delivery should include:

(i) developing curricula that are adapted to the current level of indigenous and acquired technology of the people in order to cater for the peculiar needs of the varying and changing clientele to accommodate a much wider spectrum of needs and aspirations of the people;

(ii) establishing adult literacy classes geared towards making every member of the society environmentally literate with a view to promoting the productive power of every citizen for rural transformation and sustainable development;

(iii) determining major environmental education objectives and developing policies and strategies for effective literacy campaigns;

(iv) reviving environmental awareness education initiatives to achieve the goals of mass education.

(v) identifying target groups in the communities for the purpose of training and awareness creation on environmental issues; and

(vi) identifying the perceived needs of the communities and establishing skill-up-grading programmes and training programmes for farmers and craftsmen thereby promoting better living within the communities (AnijahObi, 2001).

There is no doubt that a country that is environmentally literate is most likely to make a success of its development. Where the significance of the environment is not understood, development will fail. It is therefore important to stress that no matter how the world feels about the predicament of the global environment, unless we can transmit the information and skills to the majority of the world population, it will remain the rich deposits of metal in the earth of no value to anyone. The Nigerian government and educational planners in African should encourage environmental literacy and universal basic education as prelude to achieving a sustainable society.

\section{CONCLUSION}

Everyone is affected by environmental problems and therefore, we all have a responsibility to be well informed about the environment and ways and means of solving problems arising therefore. Success depends to a large extent on how much we know and how creatively we apply this knowledge. This is why Nigeria in particular and Africa in general should, as a matter of urgency embrace the green policy which aims at promoting 
greater awareness of environmental issues and reducing the damaging impact of environmental problems in order to propel sustainable development.

There is an urgent need to reform the education sector in Africa in order to achieve the goals of wealth creation, employment generation, poverty reduction and value reorientation. It is only through development in human capital, through an efficient, relevant, and functional educational system that the nation as a whole can progress. There should be a relationship between education and other sectors because education, inspite of constituting the 'power house' of other determinants of development, should never be pursued in isolation. However, educational administrators and policy makers on their own part should begin to take positive environmental actions that could help to preserve those elements in the environment that we consider essential, beneficial and desirable. This is because education can contribute significantly to human livelihoods and the ability of people to use natural resources more effectively and sustainably.

\section{REFERENCES}

Anijah-Obi FN (2001). Fundamentals of environmental education and management. Calabar: University of Calabar Press.
FEPA (1989). National Policy on Environment. Lagos: Federal Environmental Protection Agency.

FME/UNDP (2005). Mainstreaming environment in development in Nigeria (A training manual). Abuja: Federal Ministry of Environment/UNDP publication.

Grubb M, Koch M, Munson A, Sullivan F, Thomson K (1995). The Earth Summit Agreements: A guide and assessment. London: Earthscan Publication Ltd.

MDG Report (2006) National Planning Commission. Abuja, Nigeria. UN Millennium Project (2005). Investing in Development: A practical plan to achieve the (MDGs). New York.

Meyers D (2004) Being Yourself: Essays on Identity, Action, and Social Life. Lanham, MD: Rowman and Littlefield.

Pretty JN (1995). "Participatory Learning For Sustainable Agriculture". World development 23(8):1247-1263.

Rammel C, Stagl S, Wilfing H (2007). Managing complex adaptive systems - A co-evolutionary perspective on natural resource management, Ecological Economics, 63:9-21, URL: www.sciencedirect .com

Rigg JD (2006). 'Land, farming, livelihoods and poverty: Rethinking the links in the rural South', World Development 34(1):180-202

Torri MC (2010). Power structure, gender relations and community based conservation the case study of the Sariska region, Rajasthan, India, Journal of International women's studies, 11(4), 1-18.

Wiedemann PM, Femers S (1993). "Public Participation in waste management decision making: analysis and management of conflicts", Journal of Hazardous Materials 33(3):355-368. 